\title{
Comparative Germination of Barley Seeds (Hordeum Vulgare) Soaked in Alkaline Media and Effects on Starch and Soluble Proteins
}

\section{*ABIDA PERVEEN, *IFTIKHAR IMAM NAQVI, *REHANA SHAH AND **ABID HASNAIN}

\author{
*Department of Chemistry, **Department of Food Science and Technology University of Karachi, Kaarchi-75270 Pakistan. E-mail: \\ abida2020@yahoo.com
}

\begin{abstract}
Barley seeds (Hordeum Vulgare) were germinated after soaking in different alkaline solutions of varied concentrations and $\mathrm{pH}$, at room temperature of $25^{\circ} \mathrm{C}$. The rate of germination after 48 hours of soaking of the seeds in distilled water was found to be $35 \%$ and the rate for the seeds soaked in the solutions of $\mathrm{Ca}(\mathrm{OH})_{2}, \mathrm{KOH}$ and $\mathrm{Mg}(\mathrm{OH})_{2}$ was observed as 60,66 and $62 \%$ respectively. Where-as the rate of germination for the solutions of $\mathrm{NaOH}$ and $\mathrm{NaHCO}_{3}$ remained the same as that of the water. The influence in length of rootlets was also examined as a function of the nature of the soaking solutions. Sharp increase in the length was observed in case of $\mathrm{Mg}(\mathrm{OH})_{2}$ and $\mathrm{KOH}$ while in $\mathrm{NaOH}, \mathrm{Ca}(\mathrm{OH})_{2}$ and $\mathrm{NaHCO}_{3}$ increase in rootlets length was found insignificant . Variation of starch and soluble protein contents in soaked solutions were also examined. Starch and soluble protein contents were found to be the highest in $\mathrm{NaOH}$ soaked seeds as 57.7 and $5.95 \%$ respectively, compared to 45.07 and $2.50 \%$ for the seeds soaked in water. @ JASEM
\end{abstract}

Barley (Hordeum vulgare L.) is the major cereal in many dry areas of the Middle East, North Africa and West Asia (Ceccerelli et al) and is vital for the livelihood of many poor farmers, with suggestions that it could replace wheat as the dominant crop, due to its tolerance to drought (Forster et al., 2004). It is a major food source in many N. African countries, although in Pakistan it is mainly grown for grain and straw for small ruminants during winter (Khan et al., 1999). In Pakistan, barley is grown on around 155,000 ha, of which 60,000 ha are in the North West Frontier Province (NWFP), which has the highest area of this crop and where most of the cultivated area $(1.65 \mathrm{M} \mathrm{ha})$ has an arid or semiarid climate(Ghassemi et al). Half is irrigated, of which $13 \%$ is affected by salinity, which reduces yields substantially and leads to lower incomes and increased poverty. Speed of germination and emergence is important for successful establishment (Harris, 1996). Harris et al. demonstrated that 'onfarm' seed priming i.e. soaking seeds overnight in water (surface-drying them then sowing in the normal fashion) - markedly improved establishment and early vigor of upland rice, maize and chickpea, resulting in faster development, earlier flowering, maturity and higher yields. This simple, low-cost, low-risk intervention also had positive impacts on the wider farming system and livelihoods (Harris et al., 1999 and Harris et al., 2001). Barley is more tolerant than other cereals to alkaline soils and less tolerant to acid soils. A soil of $\mathrm{pH}$ in the range of 6.0 to 8.5 is generally acceptable for plant growth. Although barley is sensitive to acidic soils, it can resist to the $\mathrm{pH}$ levels between 5.0 and 6.0, if there is active calcium in the soil environment. Barley can resist to salinity very well, and it can be sown in the soils that salinity is $8-16$ mili.mhos. For this reason, it is a good rotation crop where salinity is a problem because of irrigation.

Barley used for brewing and malt has high starch content and along with proteins, it is usually more than sufficient to provide the amino acids needed for yeast growth and the nitrogenous materials, important for forming beer foam. Compared with most other cereal crops, barley is superior in terms of drought resistance.

Germination is a one trait that has been found to greatly vary among populations (reviewed by Baskin \& Baskin, 1998). Selection is expected to favour appropriate responses to local environmental cues that synchronize germination with periods that are optimal for seedling survival. Such a selection may result in site-specific adaptation of germination traits. In a reciprocal transplant experiment with Gilia capitata from coastal and inland habitats, germination percentage of the local population was higher at both sites (Nagy \& Rice, 1997). This study was undertaken to find appropriate means to achieve increase in germination rate and enhance harmonal activity. Instead of using harmones, which are expensive, inexpensive chemicals such as $\mathrm{NaOH}$, $\mathrm{Mg}(\mathrm{OH})_{2}, \mathrm{Ca}(\mathrm{OH})_{2}$ and $\mathrm{NaHCO}_{3}$ have been tried to get faster germination, better growth of rootlets and increased starch and protein contents. These findings seem to be useful for malt manufacturers; those can employ the alkaline solutions as steeping process to significantly reduce the germination time.

\section{EXPERIMENTAL / METHODOLOGY}

$100 \mathrm{gm}$ of Barley seeds were soaked in $300 \mathrm{ml}$ of water and alkali solutions for 24 hours at room temperature of $25^{\circ} \mathrm{C}$. Soaked solutions were prepared by dissolving appropriate amounts of the respective bases $\mathrm{Ca}(\mathrm{OH})_{2}, \mathrm{Mg}(\mathrm{OH})_{2}, \mathrm{NaOH}$ and $\mathrm{NaHCO}_{3}$ in 
$300 \mathrm{ml}$ of water to obtain concentrations ranging between 0.2 to $2 \%$. Soaked seeds were evenly spread (a layer of $2 \mathrm{~cm}$ thick) in a petri dish of 6" diameter and covered by a coarse cloth, which was kept moist for $48 \mathrm{hrs}$, after which results of germination were recorded. Equal portions of the germinated and non germinated seeds were counted to compute percentage germination. The length of the rootlets of 10 seeds picked at random from the germinated samples was measured by using a foot rule. This was done to record optimum germination. Moisture in barley seeds was estimated by recording the difference in its wet weight and the weight recorded after drying them in an oven at $60^{\circ} \mathrm{C}$. Protein content of the germinated seeds was estimated by Biurate method and starch was determined by standard method.

\section{RESULTS AND DISCUSSION}

Rate of plantation also impacts crop maturity. As planting rates are reduced maturity is delayed. A tworowed barley crop planted at one bushel per acre will probably mature two days later than one planted at two bushels per acre. Low soil $\mathrm{pH}$ (soil acidity) reduces the productivity of small grain crops. Barley is most tolerant of alkaline conditions but is more sensitive to low $\mathrm{pH}$ than the other small grains. Yields of barley may be reduced on some soils if the $\mathrm{pH}$ drops much below 6.0. Under the experimental conditions, the percent germination of Barley seeds at room temperature of $25^{\circ} \mathrm{C}$ in water (control) was found to be $35 \%$. In solution of $\mathrm{Ca}$ $(\mathrm{OH})_{2}, \mathrm{KOH}$ and $\mathrm{Mg}(\mathrm{OH})_{2}$, it was observed to be 60 , 66 and $62 \%$ respectively (Table 1 ). $\mathrm{NaOH}$ and $\mathrm{NaHCO}_{3}$ produced no effect on percent germination of barley seeds (Table 1).

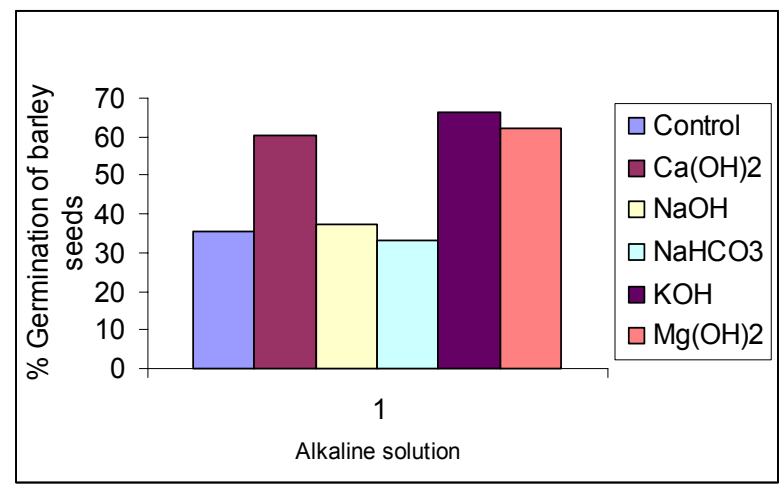

Figure 1: Bar graph showing percent germination of Barley seed with respect to different alkaline solutions.
Table 1: Maximum Germination in Alkaline solutions

\begin{tabular}{lllll}
\hline Chemicals & $\begin{array}{l}\text { Concentration } \\
(\%)\end{array}$ & $\mathrm{pH}$ & $\begin{array}{l}\% \\
\text { Germination }\end{array}$ & $\begin{array}{l}\text { Length of } \\
\text { Rootlets } \\
(\mathrm{mm})\end{array}$ \\
\hline $\begin{array}{l}\text { Control } \\
\text { (Dist. }\end{array}$ & - & 7.20 & 35.48 & 0.60 \\
Water) & & & & \\
$\mathrm{Ca}(\mathrm{OH})_{2}$ & 0.4 & 12.16 & 60.13 & 0.93 \\
$\mathrm{NaOH}$ & 0.2 & 12.28 & 37.34 & 0.72 \\
$\mathrm{NaHCO}$ & 1.0 & 8.50 & 33.08 & 0.38 \\
$\mathrm{KOH}$ & 0.2 & 12.30 & 66.12 & 1.07 \\
\hline $\mathrm{Mg}(\mathrm{OH})_{2}$ & 0.8 & 9.24 & 62.00 & 1.71 \\
\hline
\end{tabular}

Table 2: Water Absorption during Soaking (Moisture Content in Dry Seeds $=8.15 \%$ )

\begin{tabular}{lll}
\hline Seeds Soaked in & $\begin{array}{l}\text { Moisture } \\
\text { Soaking }\end{array}$ & $\begin{array}{l}\text { after } \\
\text { Water } \\
\text { Absorption (\%) }\end{array}$ \\
\hline Control & 33.19 & - \\
$\mathrm{NaOH}$ & 47.96 & 14.87 \\
$\mathrm{KOH}$ & 41.62 & 08.53 \\
$\mathrm{NaHCO}$ & 39.45 & 06.36 \\
$\mathrm{Ca}(\mathrm{OH})_{2}$ & 39.00 & 05.81 \\
\hline $\mathrm{Mg}(\mathrm{OH})_{2}$ & 36.17 & 02.98 \\
\hline
\end{tabular}

In the same sample which was used for percent germination, the length of rootlets was also determined. Sharp increase in rootlets' length was observed in $\mathrm{Mg}(\mathrm{OH})_{2}$ and $\mathrm{KOH}$ soaked solutions. These were measured as $1.71 \mathrm{~mm}$ and $1.07 \mathrm{~mm}$ against those of $\mathrm{NaOH}, \mathrm{NaHCO}_{3}$ and $\mathrm{Ca}(\mathrm{OH})_{2}$ solutions. Rootlet lengths soaked in $\mathrm{NaOH}, \mathrm{NaHCO}_{3}$ and $\mathrm{Ca}(\mathrm{OH})_{2}$ had insignificant growth, measured as $0.72,0.38$ and $0.93 \mathrm{~mm}$ respectively. These values are observed slightly greater than control rootlets, which have been $0.6 \mathrm{~mm}$.

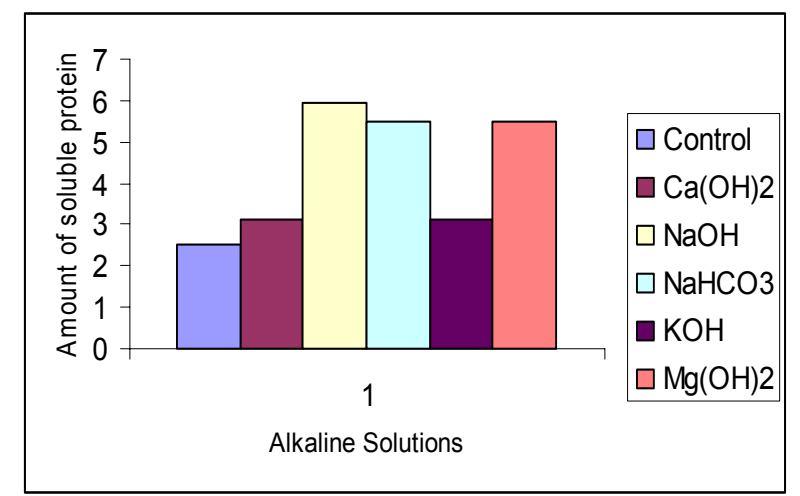

Figure 2: Soluble proteins show different behaviour in different alkaline solutions. 


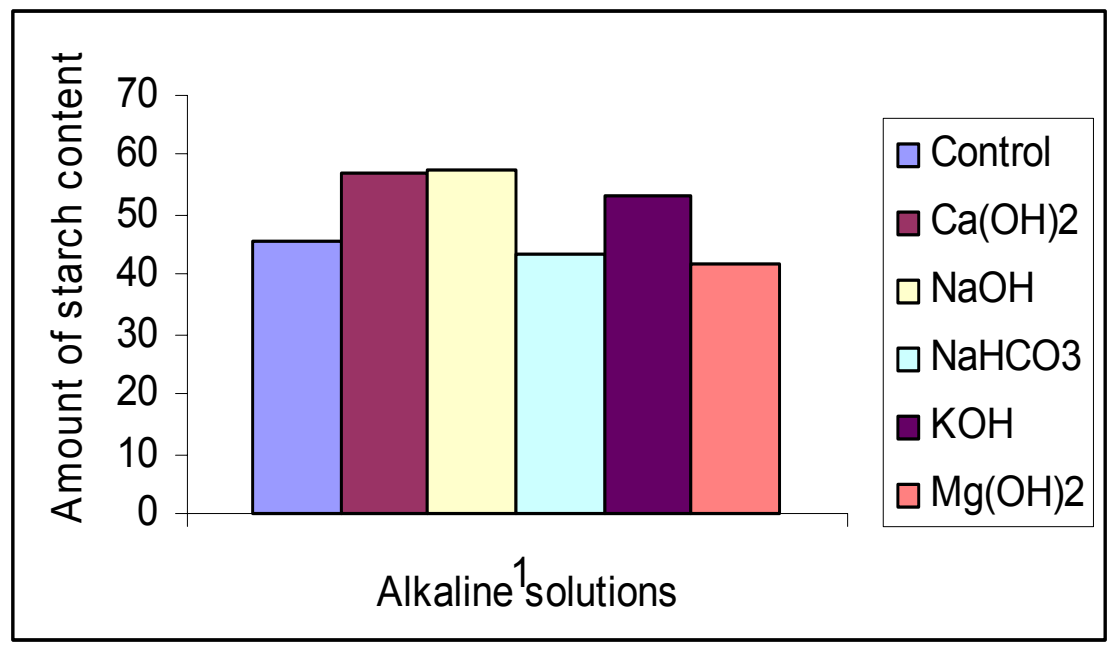

Figure 3: Graph showing the difference of starch content in different alkaline solutions.

The starch content in germinated seeds is given in Table 3. The seeds soaked in $\mathrm{Ca}(\mathrm{OH})_{2}, \mathrm{NaOH}$ and $\mathrm{KOH}$ contain more starch i.e. 57.00, 57.70, 53.00, \% respectively as compared to the control which contained $45.70 \%$ starch. The seeds soaked in $\mathrm{Mg}$ $(\mathrm{OH})_{2}$ and $\mathrm{NaHCO}_{3}$ have less quantity of starch viza viz control. These sampled show to have only 41.70 and $43.50 \%$ starch. This suggests that the amylase activity in the samples soaked in $\mathrm{Ca}(\mathrm{OH})_{2}, \mathrm{NaOH}$ and $\mathrm{KOH}$ is less than that of control and therefore starch degradation could not take place. While $\mathrm{NaHCO}_{3}$ and $\mathrm{Mg}(\mathrm{OH})_{2}$ have greater amylase activity than control i.e. amylase activity gets enhanced in the presence of $\mathrm{Mg}(\mathrm{OH})_{2}$ and $\mathrm{NaHCO}_{3}$ and the resulting degradation of sacharides reduces the starch content. Barley contains calcium, iron, a little fat, pectin (a soluble food fiber), complex carbohydrates (starch), and protein; but it is deficient in lysine. The endoproteases of germinating seeds are important for seedling development because some of them degrade storage proteins to supply the amino acids that are required for the growth of the new plant.

Table 3: Amount of Starch and protein in Different samples

\begin{tabular}{lll}
\hline Samples & Soluble Protein & Starch \\
\hline Contro & 2.50 & 45.7 \\
$\mathrm{Ca}(\mathrm{OH})_{2}$ & 3.10 & 57.0 \\
$\mathrm{Mg}(\mathrm{OH})_{2}$ & 5.50 & 41.7 \\
$\mathrm{NaOH}$ & 5.95 & 57.7 \\
$\mathrm{KOH}$ & 3.10 & 53.0 \\
\hline $\mathrm{NaHCO}_{3}$ & 5.50 & 43.5 \\
\hline
\end{tabular}

The soluble protein component was found to be $2.50 \%$ in control while it was higher in $\mathrm{NaOH}$ soaked seeds $(5.95 \%)$. In the case of $\mathrm{Mg}(\mathrm{OH})_{2}$ and $\mathrm{NaHCO}_{3}$ percent of protein is the same i.e $5.50 \%$. Similar effect has been found in $\mathrm{KOH}$ and $\mathrm{Ca}(\mathrm{OH})_{2}$. This suggests that Barley proteins are more soluble in strong alkalies.
High protein barley produces malt with low amounts of extract; is more difficult to malt, and can cause difficulties in brewing. Desirable barley protein levels in six-row malting barley are $10.5 \%$ to $13.0 \%$ and in two-row barley $10.5 \%$ to $12.5 \%$. Protein in malting barley is measured on a dry basis. Protein level is determined primarily by growing conditions. Early planting and high yields usually result in lower percent protein. Excessive rates of nitrogen fertilizer will increase protein levels but the application of nitrogen, on the basis of soil tests, to obtain optimum yields will normally have only a minor effect on the protein content of the grain. Good production practices that increase yield will generally tend to reduce protein levels. In many parts of Pakistan barley is grown not only as a grain, but also to provide feed (fodder, straw and immature grain) for livestock (Muhammad, 1998 and Khan et al., 1999) often mixed with legumes and other cereals. It is therefore important to consider not only the grain production but also the total dry biomass, and it is clear that priming is as effective in increasing total biomass as it is for grain yield. Different alkaline solutions showed marked influence on germination rate and percent germination of barley seeds. Barley seeds germinated well at a wide range of $\mathrm{pH}$ values, ranging 8.5 to 12.3 . The rootlet lengths get also affected by alkaline strength of soaking solution as well as the type of alkali.

Soluble protein contents varied in all these germinated seeds which could be due to the enhanced enzymes activity of proteinase present in barley. Similarly the starch content estimated in the germinated seeds also varied. These variations could be due to the amylase present in the globulin part of the protein. Detailed knowledge of the grain protein composition may produce further insight into the relationships between protein composition and the technological properties of barley.

\footnotetext{
* Corresponding author: *Abida Perveen.
} 
The breakdown of large structural proteins is another important event during germination. These large proteins surround the starch granules, giving the grain its structural integrity. If they are not broken down the enzymes will not be able to reach their starchy substrate to convert it to sugar during the mash.
The present study reveals that germination of barley seeds is directly related to the $\mathrm{pH}$ and the cations present in the steeping medium. Table 4 gives a descriptive sight to the effect of chemical treatment on germination.

Table 4: Effect of Chemical Treatment on Germination

\begin{tabular}{|c|c|c|c|}
\hline Treatment/ Process & Chemicals & Results & Reference and Year \\
\hline $\begin{array}{l}\text { Soaking } 10 \\
\text { Hours }\end{array}$ & $\mathrm{NaOH}$ & $\begin{array}{l}\text { Improve feed } \\
\text { conversion efficiency } \\
\text { and digestibility }\end{array}$ & Podobed L.I. 1992 \\
\hline $\begin{array}{l}\text { Treatment with } \\
\text { nine phenolic acids }\end{array}$ & $\begin{array}{l}\text { Caffeic acid, chlorogenic acid, } \\
\text { P-coomaric acid, ellagic } \\
\text { and ferulic acid. } \\
\text { Gallic acid, P-hydroxy } \\
\text { benzoic acid, Syringic acid } \\
\text { and vanilic caid }\end{array}$ & $\begin{array}{l}\text { Phenolic acids effect } \\
\text { germination and seedling } \\
\text { growth. On germination paper } \\
\text { they have no effect on seed in } \\
\text { soil. }\end{array}$ & $\begin{array}{l}\text { Krogmeier, .j; } \\
\text { Bremmer J.M. } 1989 .\end{array}$ \\
\hline $\begin{array}{l}\text { Treatment with } \\
\text { organic acids }\end{array}$ & $\begin{array}{c}\text { Organic Malate, } \\
\text { Citrate and succinate }\end{array}$ & $\begin{array}{l}\text { Germination of Barley promoted } \\
\text { by Malate, Citrate and succinate }\end{array}$ & $\begin{array}{l}\text { Haashi Shigetoazv Ito } \\
\text { and Shingo } 1977 .\end{array}$ \\
\hline
\end{tabular}

\section{Acknowledgement:}

The authors thank the Dean faculty of science, University of Karachi, for providing the financial assistance during the course of this work.

\section{REFERENCES}

Ceccerelli, S. Grando, S and Van Leur, J. A. G. S (1987) Genetic diversity in barley landraces from Syria and Jordan, Euphytica, 36, 389-405.

Forster, B. P. Ellis, R. P. Moir, J. Talame, V. Sanguineti, M. C. Tuberosa, R. This, D. TeulatMerah, B. Ahmed, I. Mariy, S.A.E.E. Bahri, H. Ouahabi, M. El Zoumarou-Wallis, N. El-Fellah, M and Ben Salem, M (2004) Genotype and phenotype associations with drought tolerance in barley tested in North Africa, Ann. Appl. Biol, $144,157-168$.

Khan, M. A. Ahmad, S. Begum, I. Alvi, A. S. and Mughal, M. S (1999) Cah, Opt. Mediterr, 39, 229-233.

Ghassemi, F. Jakeman, A. J and Nix, H. A (1995) Salinisation of Land and Water Resources: Human Causes, Extent, Management and Case Studies, CAB International, Wallingford, Oxon., UK.

Harris, D (1996) The effects of manure, genotype, seed priming, depth and date of sowing on the emergence and early growth of Sorghum bicolor (L.) Moench in semi-arid Botswana, Soil Till. Res, 40, 73-88.

\footnotetext{
* Corresponding author: *Abida Perveen.
}

Harris, D. Joshi, A. Khan, P. A. Gothkar, P and Sodhi, P. S (1999) On-farm seed priming in semi-arid agriculture: development and evaluation in maize, rice and chickpea in India using participatory methods, Exp. Agric, 35 , $15-29$

Harris, D. Raghuwanshi, B. S. Gangwar, J. S. Singh, S. C. Joshi, K. D. Rashid, A and Hollington, P. A (2001) Participatory evaluation by farmers of 'on-farm' seed priming in wheat in India, Nepal and Pakistan, Exp. Agric, 37, 403-415.

Baskin, C. C. Baskin, J. M (1998) Seeds: ecology, biogeography, and evolution of dormancy and germination, San Diego, USA: Academic Press, 49-85.

Keller, M. Kollmann, J and Edwards, P. J (2000) Journal of Applied Ecology, 37, 647-659.

Wilhelmson, A. Laitila , A. Vilpola , A. Olkku, J. Kotavita , E. Fagerstedt, K. and Home, $\mathrm{S}$ (2006) Oxygen deficiency in barley (Hordeum vulgare) grain during malting, Journal of Agricultural and Food Chemistry 54 (2): 409416.

Kaiser, B. N. Gridley, K. L. Brady, J. N. Phillips, T. and Tyerman, S. D (2005) Annals of Botany, 96(5):745-754. 
Wong, J. H. Kim, Y. B. Ren, P. H. Cai, N. M. Cho, J. Hedden, P. Lemaux, P. G. and Buchanan, B. $\mathrm{B}(2002)$ Transgenic barley grain overexpressing thioredoxin shows evidence that the starchy endosperm communicates with the embryo and the aleurone, Proc. Natl. Acad. Sci. U S A, 10; 99(25): 16325-16330.

Blank C. A and Murray, T. D (1998) Influence of $\mathrm{pH}$ and matric potential on germination of Cephalosporium gramineum conidia, Plant Dis, 82, 975-978.
Ayers, A (1942) Comparison of the calcium and sulphur content of plant fluids expressed from tissues killed by autoclaving and by freezing with solid carbon dioxide, Plant Physiology, 17, 661-665.

Muhammad, D (1998) Country pasture/forage resource profiles, Pakistan. FAO Agriculture Department, Grassland and Pasture Crops Section.

Umrani, A.P., English, P.R., and Younie, D (1995) Range land in Pakistan. Asian Livestock, Bangkok, Thialand. Xx (3):30-36.

www.agr.gov.sh.ca/default.asp.

* Corresponding author: *Abida Perveen. 